been the discovery of very great similarities between apparently diverse languages. No language has rules of the kind: 'Make a question by reversing the word of the statement'. All languages have rules which have to be formulated in terms of word classes and grammatical categories. There are plainly considerable constraints on the sorts of rules which human languages have. But until we have grammars of more of them, we will not know the range of possibilities.

From a Stout Centre seminar on 18 July 1990.

\title{
Musical images : A New Zealand historical journey 1840-1990
}

\section{CHRISTOPHER BLAKE}

On 14 September 1990 Christopher Blake, manager-designate of The Concert Programme of Radio New Zealand, composer and General Manager of the Auckland Philharmonia opened the exibiition 'Musical Images : A New Zealand historical journey 1840-1990', in the National Library Gallery in Wellington. In printing his speech for that occasion we also mark the 75th birthday of Douglas Lilburn, who has been a generous friend to the Stout Research Centre since its inception in 1983, with many important donations to the library.

In early January 1989 I was standing on the end of a jetty in a secluded bay in the Marlborough Sounds, a place where I have spent much time over the years. It was early evening. Perfectly calm. The sea water was a rich, velvety emerald and murmuring gently. The air was filled with the sounds of birds calling and singing in a chorus of rich and vibrant profusion. For a sudden and brief instant - perhaps five or ten seconds at most I heard an almost exact replication of the bird song I had recreated in a piece of music about this special place written several years earlier. The effect on me was literally hair-raising! Nowhere else in the world could these sounds be heard. Nowhere else in the world could these sounds evoke the sensations that I experienced. Musically unsophisticated though this anecdote may be, perhaps this was my first understanding of the words 'New Zealand' as a composer and a musician. Perhaps the first time I had a real understanding of their implications and possibilities.

This exhibition is subtitled 'a New Zealand historical journey'. My experiences in the Marlborough Sounds were part of the personal journeys we are all obliged to make. But this is recent history. Consider a part of this journey which took place forty years ago:

'On the way up here in the night train we stopped at National Park, and in the moonlight I could see an uncanny picture of Ngauruhoe and Ruapehu. I was so excited by this that I hung out of the door of the carriage as we came from National Park down to Raurimu at the foot of the Spiral. There was something very strange about that experience of speeding through the night with the vivid night smell of the bush country all around me.

At that moment the world that Mozart lived in seemed about as remote as the moon, and in no way related to my experience. What my feelings were I don't really know until some one can make them articulate in painting or poetry or in music'.

Many of you will recognise these words. They were spoken by Douglas Lilburn in 1946 at the first Cambridge Summer School of Music - itself a seminal undertaking in the development of New Zealand music initiated by the journeys of another intrepid musical traveller - Owen Jensen.

The gentle irony of these words is that at the time they were spoken Douglas Lilburn had in fact already made them articulate in music - an inexplicable distillation of 'New Zealandness' which in the ultimate, means something more to us than others can truly understand. 
The symmetries of his achievement are irresistible. Quintessential early works such as - the overtures Aotearoa, Festival and Drysdale and the cantata Prodigal Country were part of the centennial celebrations of 1940 when Douglas Lilburn was a youthful twenty-five year old. Today, in 1990, we celebrate the composer at seventy-five years and an anniversary of 150 years of nationhood.

The works of the intervening fifty years are all about that 'something very strange', - 'the vivid night smell of the bush country' and the challenge to others to make the New Zealand journeys that are their own version of a 'hair-raising' experience in the Marlborough Sounds. Within this exhibition the maps and routes of this musical traveller are laid out for us all to experience and understand. This is an appropriate and timely tribute to the work of this great New Zealand artist for which we owe curator Jill Palmer a resonant accolade.

Douglas Lilburn's journey is part of a larger flow. A flow expertly woven and interpreted by curator John Mansfield Thomson to whom I offer congratulations and thanks for the benefits of his wisdom and knowledge in finding and making these pathways.

Music is the province and property of all human kind. Of people from all walks of life, backgrounds, origins and beliefs. It is simultaneously their servant, their reflection and their release. And each place and each time has its own music. And each music has the unique ability to translate across time, borders and barriers whatever they may be - social, physical or intellectual.

On this journey backwards through time we will discover the music that was brought to these shores by the early settlers; the music that was here long before they arrived; the objects that were and are a part of music here; and the uses and functions of music in the life of New Zealanders in its myriad manifestations.

And the music we will discover is a part of the living tradition of music in New Zealand. Music, almost more than any of the arts, builds and grows on what has gone before. Be it conscious or unconscious the sights and sounds of this exhibition have, through the passage of time each contributed to the musics of 1990 - our music of the concert hall, the recital chamber, the dance hall, school room, pub, party, after-match function. They are all part of it - I urge you to celebrate it, enjoy it and above all embrace it.

I am delighted to declare this exhibition open.

\section{An operatic tradition}

\section{ADRIENNE SIMPSON in conversation with J.M.THOMSON}

Adrienne Simpson's recent seminar at the Stout Centre on the Simonsen Opera Company gave striking evidence of the popularity of opera in 19th-century New Zealand, not only in cities but in the many small towns which the travelling companies included in their schedules. Today, opera is the cinderella of the arts, rebuilding in regional form after the fateful decision of the $Q E I I$ to withdraw national funding from the New Zealand Opera Company and its successor, the New Zealand National Opera. In this interview, J.M. Thomson asks Adrienne Simpson why opera is such a potent force in a country where, in the view of today's policy makers, it is often considered irrelevant to cultural aspirations. In other words, how meaningful is opera to present-day New Zealand?

Any art form enjoyed by so many New Zealanders has to be relevant. Opera is one of the few growth forms in New Zealand. More and more people are attending opera, wanting to participate in it and, steadily, more and more professional performances are being put on. A Hillary Commission report carried out a couple of years ago showed that more New Zealanders participate in and enjoy the arts than take part in or watch rugby. This country produces fine operatic singers with much the same prodigality as it produces All Blacks. In proportion to its 